\title{
Ribbed moraines formed during the retreat of the Scandinavian ice sheet from eastern Himmerland, NE Jylland, Denmark
}

\author{
Hans Lerche, Peter Roll Jakobsen and Stig A. Schack Pedersen
}

The glacial geology of Himmerland in the north-eastern part of Jylland, south of Limfjorden (Fig. 1) has never received any special attention. However, the occurrence of parallel ridges south of Torup was mentioned by Milthers (1948) who interpreted them as marginal moraines. The ridges were recently studied during mapping of eastern Himmerland. Systematic geological mapping of the area north and south of Mariager Fjord started in 2009 and was completed in 2013 (map sheet 1316 III; Pedersen et al. 2013). This was followed by the map sheet to the north (1316 IV). During the recent mapping the extent of the terrain with parallel ridges was determined (Fig. 2); the western boundary is found in Rold Skov (Pedersen \& Jakobsen 2005) and the eastern boundary follows an ancient coastline in eastern Himmerland. The most impressive parallel ridges occur in a forested area east of Madum Sø where the top level of the ridge crests reaches an elevation of $95 \mathrm{~m}$ a.s.l. However, the majority of the crests are at $60-70 \mathrm{~m}$

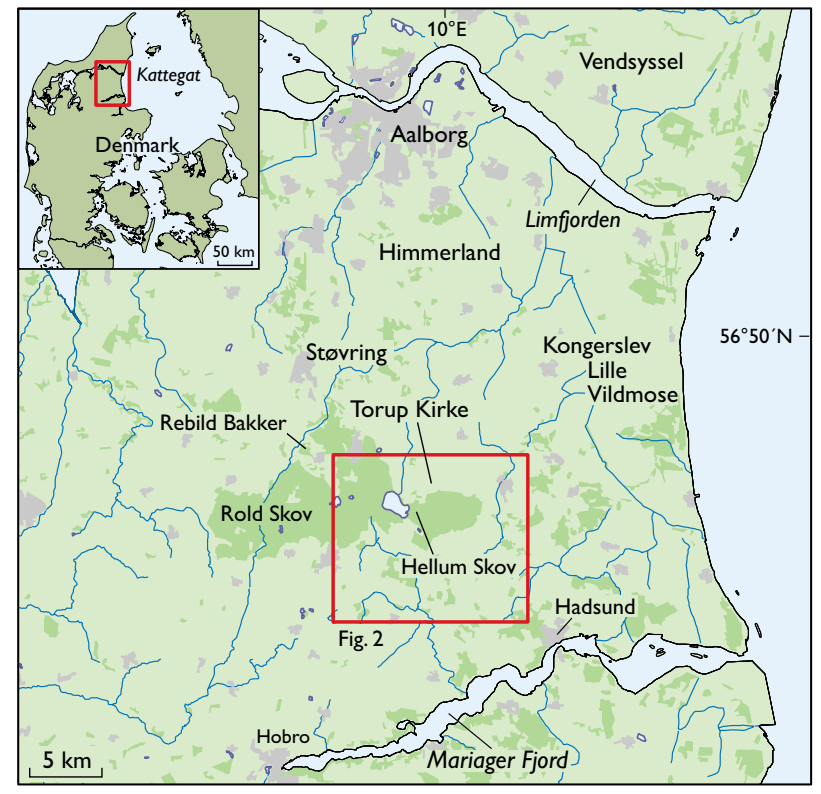

Fig. 1. Map of the north-eastern part of Himmerland where systematic geological mapping has been conducted over the past five years. The area with moraine ridges is indicated by a rectangle. The locations of place names mentioned in the text are shown. a.s.l. and most of the ridges are $c .10-15 \mathrm{~m}$ high. The sediments in the ridges are dominated by coarse-grained sand and gravel, and accumulations of erratic boulders are found on the surface of the ridges.

After completion of the mapping of the area, we decided to make a detailed investigation of the ridges using groundpenetrating radar (GPR) to map the internal structures of the ridges. We also studied sections in a small gravel pit at the northern boundary of Siem Skov (Figs 3, 4).

The aim of this paper is to describe the terrain with parallel ridges, which we interpret as ribbed moraines. We discuss the geological setting of the ridges in relation to the data acquired during the systematic geological mapping and the accompanying GPR survey. A glaciodynamic model for the formation of the ridges is proposed related to the recession of the ice that had its source area in south central Sweden.

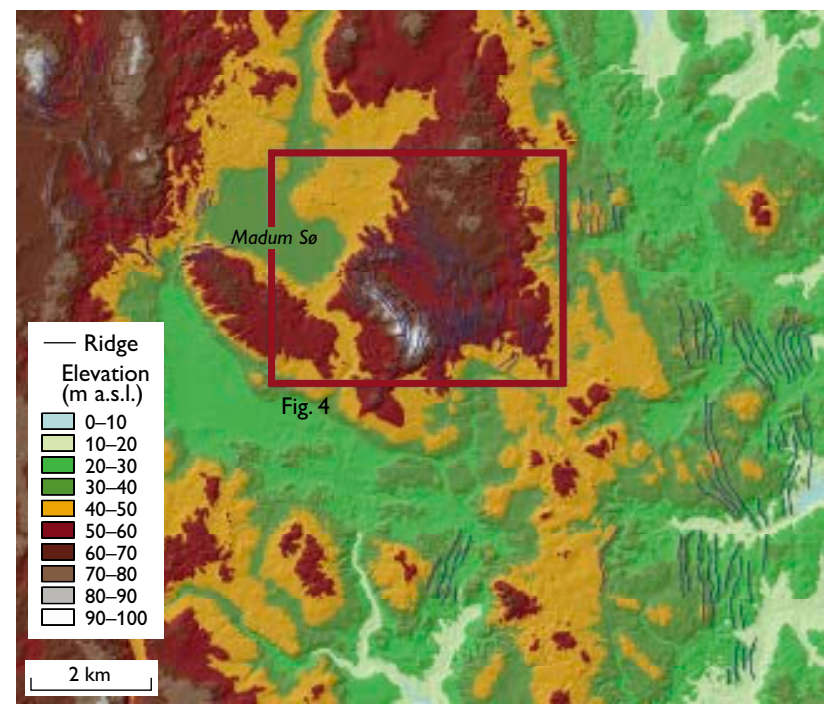

Fig. 2. LiDAR-based digital elevation model of the study area showing moraine ridges. Most of the ridges are found in three separate areas. The most densely spaced and largest ridges occur in the central area. 


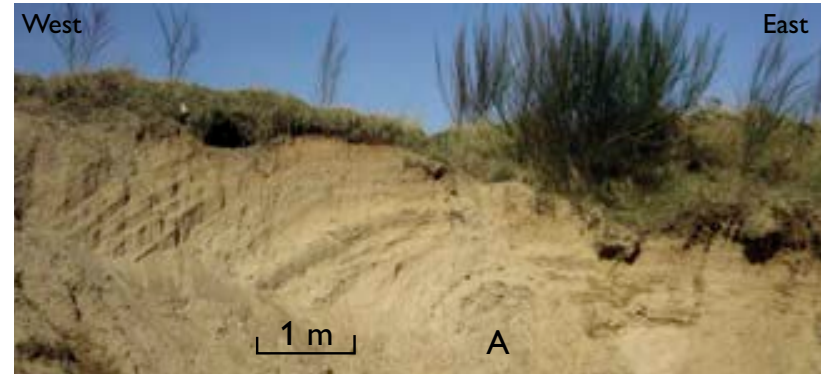

Fig. 3. Exposure in a small gravel pit located c. $1.2 \mathrm{~km} \mathrm{SSW}$ of Torup Kirke showing a section through one of the ridges. West of the anticline (A) dipping layers of glaciaofluvial sand and gravel are seen, and east of the anticline layers of flow till occur. The architecture can be compared to the structures seen in the GPR profiles (Fig. 5). Photograph: Elina Kamla.

\section{Geological setting}

The bedrock in Himmerland is dominated by Maastrichtian chalk which is exposed in pits throughout the region. An erosional unconformity separates chalk from Quaternary deposits. Major parts of the region between Mariager Fjord and Limfjorden are covered by glaciofluvial sand that reaches a thickness of $c .40 \mathrm{~m}$ at Hadsund. In the small gravel pit at the northern boundary of Siem Skov, the succession begins with a glaciolacustrine unit, which increases in thickness towards the east. This unit is interpreted as a palaeo-Kattegat deposit and may correlate with the Lønstrup Klint Formation in Vendsyssel (Pedersen 2005). It is overlain by glaciofluvial sand and gravel that may correlate with the Rubjerg

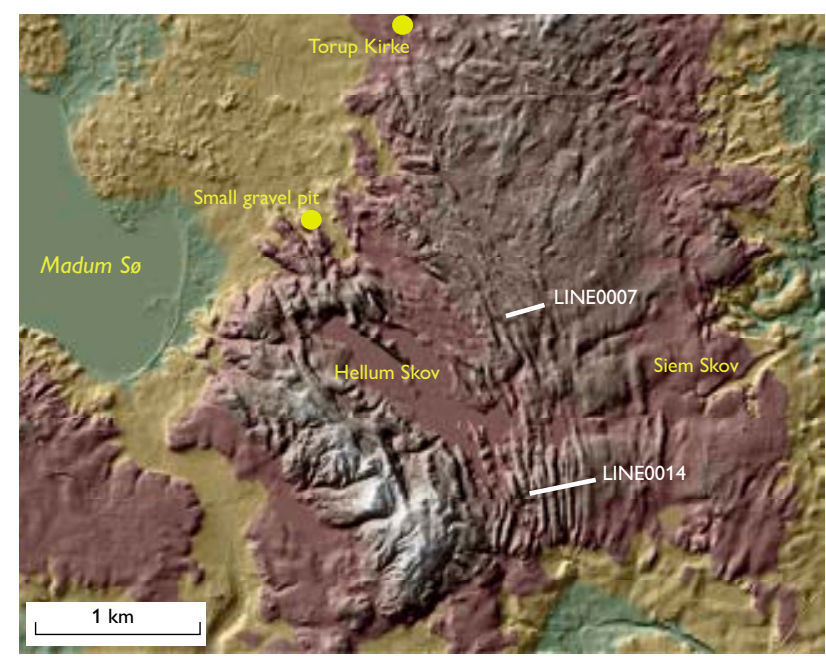

Fig. 4. Hill shade image of the central part of the ridge terrain. The ridges are almost parallel, mainly $\mathrm{N}-\mathrm{S}$-oriented but $\mathrm{NW}-\mathrm{SE}$-oriented in the north. The locations of the two GPR profiles (Fig. 5) are also shown. LINE0007 was acquired in a spruce plantation across relatively smooth ridges, whereas LIN0014 was acquired along a gravel road crossing 11 steep-sided ridges.
Knude Formation (Pedersen 2005). These proglacial deposits of the glaciodynamic sequence (according to the concept of Pedersen 2012) are overlain by c. $3 \mathrm{~m}$ of till. The till is classified as a sandy till; it contains indicator boulders from the Oslo Fjord region and its fabric indicates an ice-flow direction from north to south. Based on this ice movement direction the till is correlated with the Kattegat Till Formation (Houmark-Nielsen \& Kjær 2003; Pedersen 2005). The top of the till is at $56 \mathrm{~m}$ a.s.l. in Siem Skov where it forms the base of the $10-25 \mathrm{~m}$ high ridges.

Meltwater related to the Swedish Ice Advance only played a small role in the region with the parallel ridges. To the west, glaciofluvial deposits from the Swedish Ice Advance are found in the upper part of the Rebild Bakker (Pedersen \& Jakobsen 2005). After the parallel ridges had formed, depressions were created in the landscape due to melting of bodies of stagnant ice that were left from the retreating ice front. During the early Holocene valleys were eroded when the relative sea level was low.

\section{Geomorphology of the parallel ridges}

The elongate ridges cover an area of $15 \times 8 \mathrm{~km}$. Most of them are $\mathrm{N}$-S-oriented, but there are $\mathrm{NW}$-SE-oriented ridges in the north-western part of the area. The ridge density is highest in the central part of the area, in Hellum Skov and Siem Skov (Fig. 4) where the ridges reach elevations of $70 \mathrm{~m}$ a.s.l. and are $c .10 \mathrm{~m}$ high. The mean spacing between the ridges is $48 \mathrm{~m}$ in Hellum Skov and Siem Skov and the longest ridges are $c .2500 \mathrm{~m}$ long. Towards the east and south, ridges may still be recognised but are somewhat obscured. In these areas, ridge crests are at $c .30 \mathrm{~m}$ a.s.l. and the ridges are $5-10 \mathrm{~m}$ high.

\section{Georadar survey of the parallel ridges}

In September 2013, ground penetrating radar (GPR) surveys were carried out in Hellum Skov where the most pronounced ridge terrain is found. An EKKO 100TM device mounted on a cart was used, and six lines perpendicular to the ridges were recorded; five lines in the northern part of the forest and one line $c .1 \mathrm{~km}$ to the south. Transmitter voltage was $400 \mathrm{~V}$ and antenna frequency was centered at $100 \mathrm{MHz}$. The antennas were oriented broadside to the survey direction and separated by $1 \mathrm{~m}$. Traces were recorded every $20 \mathrm{~cm}$ and consist of stacks of eight.

Two representative profiles, LINE0007 and LINE0014, illustrate the internal architecture of the ridges (Fig. 5). Assuming a mean velocity of $0.1 \mathrm{~m} / \mathrm{ns}, 1 \mathrm{~m}$ equals $20 \mathrm{~ns}$. In LINE0014 the layers below the ridges are predominantly 
Fig. 5. Two examples of processed ground-penetrating radar records and their interpretations (LINE0014 is divided into two parts). The GPR data were processed using Reflex2DQuick analysis. The following steps were followed prior to the interpretation of the data: (1) X-axis flip, (2) move start time to $-45.2 \mathrm{~ns}$, (3) normal move-out, $1 \mathrm{~m}$ separation, (4) dewow noise filtered, time window $10 \mathrm{~ns}$, (5) bandpass frequency, 20/187 $\mathrm{MHz},(6)$ topographic migration, summation width 50 traces, (7) divergence compensation gain, scaling value 1 and (8) topographic correction, square interpolation. Our knowledge of radar-wave velocity variations in the survey area is limited, and hence we refrained from converting the recorded two-way travel time to depth. However, hyperbola velocity adaptions provided approximate mean velocities for each survey line.
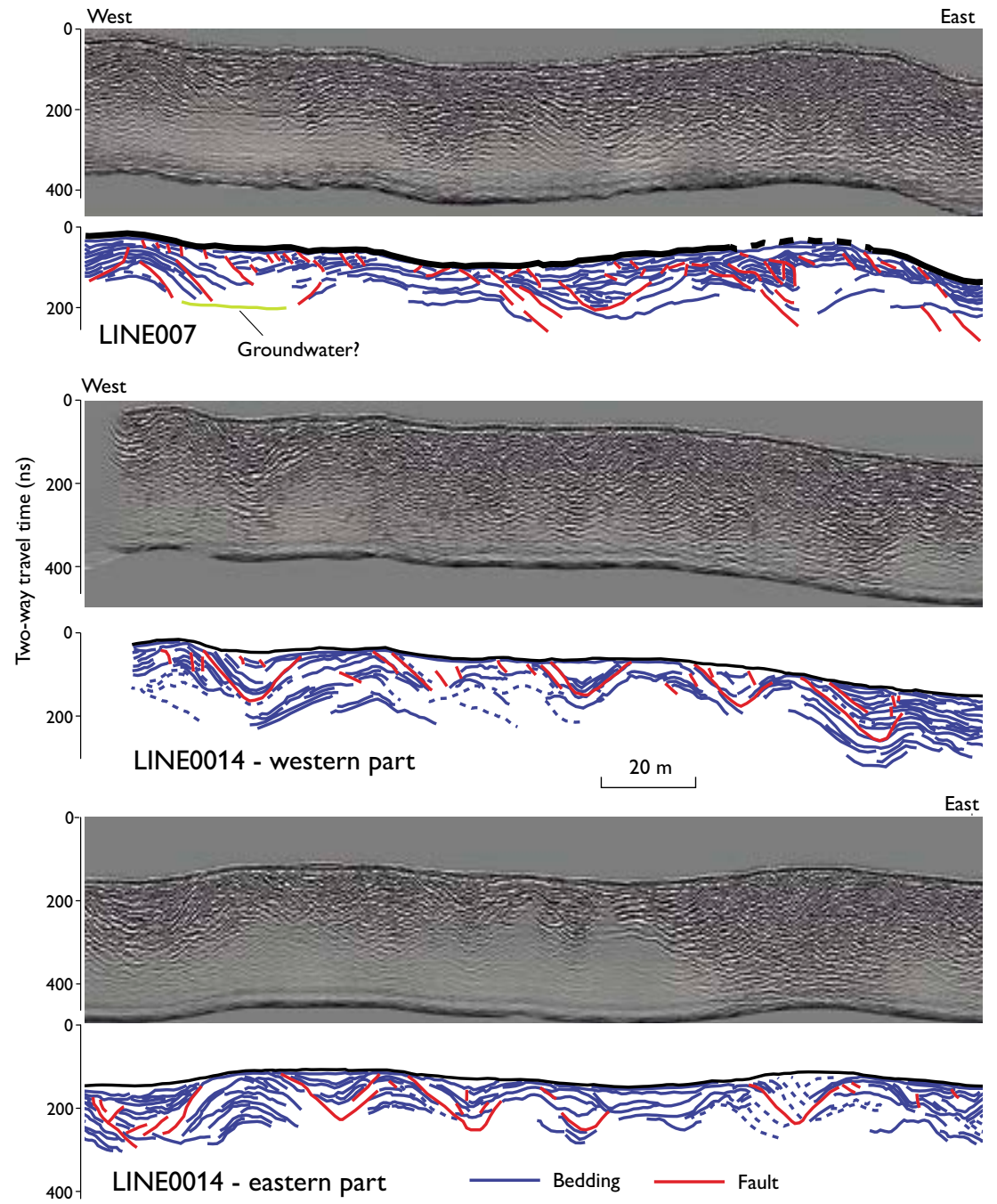

subparallel anticlines, whereas layers below depressions are dominantly subparallel synclines. In both profiles two types of faults are found: (1) small, dominantly eastward-dipping faults and (2) larger, possibly superimposed folded thrust faults, which can be traced from near the surface down to 7-10 $\mathrm{m}$ below the surface (Fig. 5 ).

\section{Formation of the ridges}

The small E-dipping faults recognised in the GPR profiles are interpreted as thrust faults caused by pushing from the east. Small W-dipping faults may indicate landslides on steep ridge flanks. Large thrust faults are interpreted as listric faults with décollement surfaces $c$. 7-10 m below the ground. The folded lower layers of LINE0014 suggest ductile deformation within the ridges and the depressions.

GPR data indicate that the ridges were formed by ice pushing from the east under non-permafrost conditions. We suggest that the ridges reflect a net ice recession with a mean rate of $c .50 \mathrm{~m} /$ year, but with a number of small advances (Fig. 6). The east-west extent with ridges is almost $10 \mathrm{~km}$ wide, corresponding to a period of $c .200$ years. A similar magnitude of recession rate of the Scandinavian Ice Sheet has been suggested for Vendsyssel, where recession from the coastal area along Kattegat north of Limfjorden is estimated to have occurred in the interval from 19 to $18.5 \mathrm{ka}$ (Sandersen et al. 2009). We suggest that shortly after termination of the Last Glacial Maximum temperature increased rapidly, which lead to a significant recession of the ice margin.

The moraines show some similarities to de Geer moraines (De Geer 1940; Lundquist 1986; Lundquist \& Viborg 1998; Lindén \& Möller 2005). However, de Geer moraines formed in water depths of $150-250 \mathrm{~m}$, during retreat of a grounding line with a calving glacier front. In contrast, the Himmerland moraines formed on dry land. 


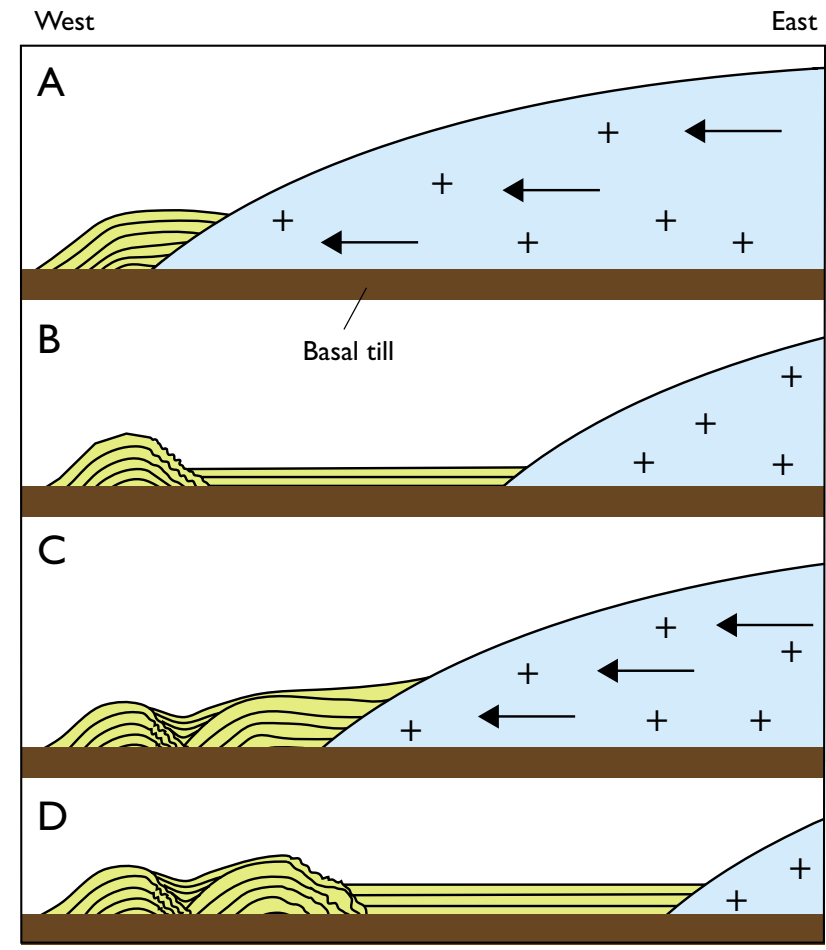

Fig. 6. Conceptual model showing the formation of moraine ridges in north-eastern Himmerland. A: In winter the glacier front advances, pushing up and deforming deposits in front of the glacier. B: In summer the mass balance of the glacier is negative and the glacier front recedes. The proximal part of the deformed deposits collapses and a ridge is formed. A new outwash fan forms between the glacier margin and the ridge. $\mathbf{C}$ : The next winter the new outwash fan is pushed up and deformed. Syntectonic deposition in the form of flow till and alluvial sediments also occurs. D: The next summer another outwash fan is formed.

\section{Conclusions}

As part of the systematic mapping of eastern Himmerland, a detailed investigation was made of a terrain with parallel ridges located in a $120 \mathrm{~km}^{2}$ large area centred on Siem Skov. The individual ridges are up to $c .2 .5 \mathrm{~km}$ long. The ridges are $10-25 \mathrm{~m}$ high, and the spacing between the ridge crests varies from 50 to $100 \mathrm{~m}$. The parallel ridges are interpreted as ribbed moraines that formed during recession of the ice margin at $c .19 \mathrm{ka}$. The detailed architecture of the ridges was investigated by GPR surveys which show an integrated depositional and deformational dynamic picture with narrow and steep-sided depressions filled with flow-till materials contemporaneous with fold-push and up-thrusting.

\section{References}

De Geer, G. 1940: Geochronologia Suecica, Principles. Kungliga Svenska Vetenskapsakademiens Handlingar Ser. III 18(6), 367 pp.

Houmark-Nielsen, M. \& Kjær, K.H. 2003: Southwest Scandinavia, 40-15 kyr BP: palaeogeography and environmental change. Journal of Quaternary Science 18, 769-786.

Lindén, M. \& Möller, P. 2005: Marginal formation of De Geer moraines and their implications to the dynamics of grounding-line recession. Journal of Quaternary Science 20, 113-133.

Lundqvist, J. 1986: Late Weichselian glaciation and deglaciation in Scandinavia. Quaternary Science Reviews 5, 269-292.

Lundqvist, J. \& Viborg, L. 1998: Isavsmältning och israndlinjer i Sverige and Lokaler i Sverige. In: Andersen, S. \& Pedersen, S.A.S. (eds): Israndslinier i Norden, 61-81 and 161-215. Copenhagen: Nordisk Ministerråd.

Milthers, V. 1948: Det danske Istidslandskabs Terrænformer og Deres Opstaaen. Danmarks Geologiske Undersøgelse III. Række 28, 234 pp. (with summary in English).

Pedersen, S.A.S. 2005: Structural analysis of the Rubjerg Knude glaciotectonic complex, Vendsyssel, northern Denmark. Geological Survey of Denmark and Greenland Bulletin 8, 192 pp.

Pedersen, S.A.S. 2012: Glaciodynamic sequence stratigraphy. In: Huuse, M. et al. (eds) 2012: Glaciogenic Reservoirs and Hydrocarbon Systems. Geological Society (London) Special Publication 368, 29-51.

Pedersen, S.A.S. \& Jakobsen, P.R. 2005: Geologisk kortlægning af statsskovarealerne i Rold Skov. Systematisk geologisk kartering af statsskovarealerne i Rold Skov, som udgør dele af 1:25 000 kortbladene 1216 I S og 1216 II NØ, nordlige Jylland. Danmarks og Grønlands Geologiske Undersøgelse Rapport 2005/81, 28 pp.

Pedersen, S.A.S., Jakobsen, P.J., Tougaard, L. \& Gravesen, P. 2013: Geological map of Denmark 1:50 000, map sheet Mors, NW Denmark. Geological Survey of Denmark and Greenland Bulletin 28, 29-32.

Sandersen, P.B.E., Jørgensen, F., Larsen, N.K., Westergaard, J.H., \& Auken, E. 2009: Rapid tunnel-valley formation beneath the receding Late Weichselian ice sheet in Vendsyssel, Denmark. Boreas 38, 834851.

\footnotetext{
Authors' addresses

H.L., Department of Geosciences and Natural Resource Management, University of Copenhagen, Øster Voldgade 10, DK-1350 Copenhagen K, Denmark. E-mail: hans_lerche@hotmail.com

P.R.J. \& S.A.S.P., Geological Survey of Denmark and Greenland, Øster Voldgade 10, DK-1350 Copenhagen K, Denmark.
} 